\title{
Reaction of 1,2-Cyclic Sulfites with Some Soft Nucleophiles. Formation of Enantiomerically Pure $\gamma$-Lactones
}

\author{
Kirsten Nymann and John S. Svendsen*
}

University of Troms $\varnothing$, Institute of Mathematical and Physical Sciences, Department of Chemistry, N-9037 Troms $\emptyset$, Norway

\begin{abstract}
Nymann, K. and Svendsen, J. S., 1998. Reaction of 1,2-Cyclic Sulfites with Some Soft Nucleophiles. Formation of Enantiomerically Pure $\gamma$-Lactones. - Acta Chem. Scand. 52: 338-349. (C) Acta Chemica Scandinavica 1998.

The reaction between 1,2-cyclic sulfites and soft carbon centered nucleophiles has been investigated. For monosubstituted cyclic sulfites, the main products were $\gamma$-lactones or acetoxy esters. For 1,2-disubstituted cyclic sulfites, cyclopropanes, carbonate and dioxolanes were the main products. A mechanistic rationale for the product formation is presented.
\end{abstract}

The chiral $\gamma$-lactone functionality is prevalent in many natural products. ${ }^{1} \gamma$-Lactones are found in flavour components, ${ }^{2-4}$ in feromones, ${ }^{5-12}$ in lignans, ${ }^{13}$ and in cellular signalling substances. ${ }^{14-16}$ In addition, substituted $\gamma$-lactones have been widely utilised as chiral templates for the preparation of complex natural products. ${ }^{17-20}$ The enantiomers can show striking differences in biological activity, and as a result of this, a large number of methods for the asymmetric synthesis of lactones have been developed recently. ${ }^{21-36}$

Cyclic sulfites and sulfates have similar synthetic potential to epoxides and have been proposed as new synthetic epoxide equivalents. The electrophilic chemistry of cyclic sulfates and sulfites has recently been reviewed. ${ }^{37,38} \mathrm{We}$ have previously reported that a cyclic sulfite can react with dimethyl malonate anion to form a $\gamma$-lactone, albeit in low yield. ${ }^{39}$ 1,2-Cyclic sulfites are most conveniently prepared from vicinal diols, which are now available in high enantiomeric excesses by asymmetric dihydroxylation (AD) of alkenes. ${ }^{40,41}$

In this work we have explored the possibility of preparing enantiomerically pure $\gamma$-lactones from the readily available vicinal-diols via 1,2-cyclic sulfites. Enantiomerically pure cyclic sulfites have been treated with soft carbon nucleophiles such as the anions of $\beta$-diesters or $\beta$-keto esters. These nucleophiles alkylate the cyclic sulfites forming $\gamma$-hydroxy esters and acetoxy esters which can subsequently cyclise to $\gamma$-lactones. We have also studied the efficiency, the enantioselectivity and some limitations of this process.

* To whom correspondence should be addressed.

\section{Results and discussion}

The chiral diols (1a-g) were prepared in good yields and excellent enantiomeric purities by asymmetric dihydroxylation $^{40,41}$ of the corresponding alkenes. As shown in Scheme 1, the cyclic sulfites $(\mathbf{2 a}-\mathbf{g})$ were formed by treating diols 1a-g with thionyl chloride in dichloromethane. The yields of cyclic sulfites were good, and, with the exception of the symmetrical cyclic sulfite $2 \mathbf{f}$, a near equimolar ratio of diastereomeric cyclic sulfites were formed. No epimerisation of the chiral carbon atoms during the formation of the cyclic sulfites could be detected.

Reactions with dimethyl malonate and dimethyl 2-methylmalonate enolates. We have previously reported that dimethyl malonate anion reacts with cyclic sulfite $\mathbf{2 a}$ in DMF to give the $\gamma$-lactone $(3 S, 4 R)-4,5$-dihydro-3methoxycarbonyl-4-phenyl-2(3H)-furanone $\mathbf{3 a}, \mathrm{H}$ in low yield. ${ }^{39}$ The variation in yield of lactone $3 \mathrm{a}, \mathrm{H}$ as a function of different solvents and bases was investigated. In DMSO, acetonitrile and THF, the yield of lactone 3a, $\mathrm{H}$ decreased, and in HMPA only diol 1a could be isolated upon completion of the reaction. In DMF, or mixtures of solvents such as DMF-THF $(4: 1)$ or DMFacetonitrile $(4: 1)$, the yields were higher than in the other solvents used. Sodium hydride was the preferred base and was found to give superior yields compared with lithium hydride, dimsyl sodium, potassium tertbutoxylate and LDA. The best yields so far were obtained by heating the cyclic sulfite in DMF at $80^{\circ} \mathrm{C}$ for $2 \mathrm{~h}$ with a threefold excess of dimethyl malonate anion generated by sodium hydride. Under these conditions cyclic sulfite 


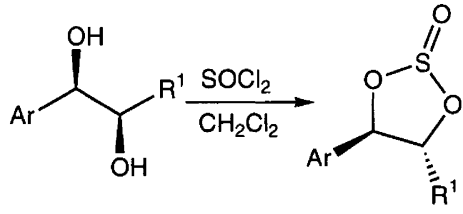<smiles>C[R]C(C(C)=O)C(C)=O</smiles>

\section{$\mathrm{NaH}, \mathrm{DMF}$}

1

$$
\begin{aligned}
& \text { a: } \mathrm{Ar}=\mathrm{Ph}, \mathrm{R}^{1}=\mathrm{H} \\
& \text { b: } \mathrm{Ar}=p-\mathrm{MeOOC}-\mathrm{C}_{6} \mathrm{H}_{4}, \mathrm{R}^{1}=\mathrm{H} \\
& \text { c: } \mathrm{Ar}=2-\mathrm{Naphthyl}, \mathrm{R}^{1}=\mathrm{H} \\
& \text { d: } \mathrm{Ar}=p-\mathrm{Cl}_{-}-\mathrm{C}_{6} \mathrm{H}_{4}, \mathrm{R}^{1}=\mathrm{H} \\
& \text { e: } \mathrm{Ar}=p-\mathrm{MeO}-\mathrm{C}_{6} \mathrm{H}_{4}, \mathrm{R}^{1}=\mathrm{H} \\
& \text { f: } \mathrm{Ar}=\mathrm{Ph}, \mathrm{R}^{1}=\mathrm{Ph} \\
& \text { g: } \mathrm{Ar}=\mathrm{Ph}, \mathrm{R}^{1}=\mathrm{Me}
\end{aligned}
$$

Scheme 1.

2a produced the $\gamma$-lactone $(3 \mathbf{a}, \mathrm{H})$ as shown in Scheme 1 in $63 \%$ yield (Table 1) with an enantiomeric excess greater than $95 \%$ (as determined by ${ }^{1} \mathrm{H}$ NMR spectroscopy using tris[3-(heptafluoropropylhydroxymethylene)-(+)-camphorato]europium $\left[\mathrm{Eu}(\mathrm{hfc})_{3}\right]$ as a chiral shift reagent and benzene- $d_{6}$ as the solvent). The $400 \mathrm{MHz}$ NMR spectrum of $3 \mathrm{a}, \mathrm{H}$ revealed that the lactone is formed as a single epimer suggesting that the stereochemically labile center at C-3 adopts the thermodynamically more stable $3 S, 4 R$-arrangement (the phenyl group at C-4 is trans relative to methoxycarbonyl substituent). When the reaction mixture was heated for prolonged periods, other products, (4R)-4,5-dihydro-4phenyl-2 $(3 H)$-furanone $(\mathbf{4 a}, \mathrm{H})$, dimethyl (2S)-2phenylcyclopropane-1,1-dicarboxylate (5a), and the car-<smiles>[2H][C@]1(C(=O)OC)C(=O)O[C@@H]([CH])[C@H]1C</smiles>

3<smiles>COC(=O)C1(C(C)=O)[C@@H](Cl)[C@@H]1Cl</smiles><smiles>[R]C1C(=O)O[C@@H]([Tl])[C@@H]1[3H]</smiles><smiles>[1H][C@H]1OC(=O)O[C@@H]1[TeH]</smiles>

bonate (4R)-4-phenyl-1,3-dioxolan-2-one $\quad(\mathbf{6 a})$ were formed in minor quantities $(<1 \%)$.

The $\gamma$-lactone is formed by an $\mathrm{S}_{\mathrm{N}} 2$ displacement on the benzylic position on the cyclic sulfite as depicted in Scheme 2 . The reactions were not performed with total exclusion of water and the resulting sulfite monoester $\mathbf{8 a}, \mathrm{H}$ was hydrolysed to the $\gamma$-hydroxy ester $\mathbf{9 a}, \mathrm{H}$ which spontaneously cyclised to the $\gamma$-lactone $3 \mathrm{a}, \mathrm{H}$. Lactone 3a, $\mathrm{H}$ will also hydrolyse and decarboxylate to lactone 4a, $\mathrm{H}$ upon increasing the reaction time. The formation of the cyclopropane by-product $\mathbf{5 a}, \mathbf{H}$ is interesting

\begin{tabular}{|c|c|c|c|c|c|c|c|c|c|}
\hline & \multicolumn{2}{|l|}{ Substrate } & \multirow{2}{*}{$\frac{\text { Reagent }}{\mathrm{R}^{2}}$} & \multicolumn{6}{|c|}{ Yield of products $(\%)$} \\
\hline & $\mathrm{Ar}$ & $\mathrm{R}^{1}$ & & 2 & 3 & 4 & 5 & 6 & 7 \\
\hline $\begin{array}{l}\mathrm{a}, \mathrm{H} \\
\mathrm{a}, \mathrm{Me}\end{array}$ & $\mathrm{Ph}$ & $\mathrm{H}$ & $\begin{array}{l}\mathrm{H} \\
\mathrm{Me}\end{array}$ & $\begin{array}{r}32 \\
3\end{array}$ & $\begin{array}{l}60+3 \\
76+1^{a}\end{array}$ & $\begin{array}{l}1 \\
8+1^{a}\end{array}$ & $<1$ & $\begin{array}{r}<1 \\
5\end{array}$ & \\
\hline $\begin{array}{l}\text { b, H } \\
\text { b, Me }\end{array}$ & $p-\mathrm{MeOOC}-\mathrm{C}_{6} \mathrm{H}_{4}$ & $\mathrm{H}$ & $\begin{array}{l}\mathrm{H} \\
\mathrm{Me}\end{array}$ & 4 & $\begin{array}{l}13+1^{a} \\
18+1^{a}\end{array}$ & $<1$ & & 9 & $\begin{array}{l}60 \\
77\end{array}$ \\
\hline $\begin{array}{l}\text { c,H } \\
\text { c,Me }\end{array}$ & 2-Naphthyl & $H$ & $\begin{array}{l}\mathrm{H} \\
\mathrm{Me}\end{array}$ & $\begin{array}{l}26 \\
37\end{array}$ & $\begin{array}{c}5 \\
20+6^{a}\end{array}$ & $\begin{array}{l}10+3^{a} \\
<1\end{array}$ & & $\begin{array}{r}11 \\
2\end{array}$ & 9 \\
\hline $\begin{array}{l}\text { d, H } \\
\text { d, Me }\end{array}$ & $p-\mathrm{Cl}-\mathrm{C}_{6} \mathrm{H}_{4}$ & $\mathrm{H}$ & $\begin{array}{l}\mathrm{H} \\
\mathrm{Me}\end{array}$ & $\begin{array}{l}2 \\
1\end{array}$ & $\begin{array}{l}63 \\
20+3^{a}\end{array}$ & $\begin{array}{l}5 \\
8+1^{a}\end{array}$ & 2 & $\begin{array}{l}5 \\
5\end{array}$ & $\begin{array}{r}5 \\
33\end{array}$ \\
\hline $\begin{array}{l}\mathbf{e}, \mathrm{H} \\
\mathbf{e}, \mathrm{Me}\end{array}$ & $p-\mathrm{MeO}-\mathrm{C}_{6} \mathrm{H}_{4}$ & $\mathrm{H}$ & $\begin{array}{l}\mathrm{H} \\
\mathrm{Me}\end{array}$ & $\begin{array}{l}11 \\
12\end{array}$ & $\begin{array}{l}73 \\
33+55^{a}\end{array}$ & $\begin{array}{l}5 \\
5\end{array}$ & & & \\
\hline $\mathbf{f}, \mathrm{H}$ & $\mathrm{Ph}$ & $\mathrm{Ph}$ & $\mathrm{H}$ & 16 & & & 24 & 31 & 5 \\
\hline $\begin{array}{l}\mathbf{g}, \mathrm{H} \\
\mathbf{g}, \mathrm{Me}\end{array}$ & $\mathrm{Ph}$ & $\mathrm{Me}$ & $\begin{array}{l}\mathrm{H} \\
\mathrm{Me}\end{array}$ & $\begin{array}{l}17 \\
19\end{array}$ & 7 & & 23 & $\begin{array}{l}11 \\
16\end{array}$ & $\begin{array}{r}7 \\
36\end{array}$ \\
\hline
\end{tabular}
because this product must be formed via a double displacement, where the malonyl moiety in the sulfite ester $\mathbf{8 a}, \mathbf{H}$ is deprotonated by the excess of the basic nucleophile, and in the next step the malonyl anion

Table 1. Product distribution from the reaction between cyclic sulfites and dimethyl malonate or dimethyl 2-methylmalonate anions.

${ }^{a}$ Diastereomeric mixture. 
displaces the sulfite group in a second, intramolecular $\mathrm{S}_{\mathrm{N}} 2$ reaction. This type of reactivity has previously been described for the much more reactive cyclic sulfates, ${ }^{42}$ but is not known for epoxides, and rarely observed for cyclic sulfites.

When monosubstituted cyclic sulfites $(\mathbf{2 b}-\mathbf{e})$ were treated with dimethyl malonate anion under similar conditions, the yield of the $\gamma$-lactone generally decreased (Table 1), with the exception for the para-methoxyphenyl-substituted cyclic sulfite $\mathbf{2 e}$, where the corresponding $\gamma$-lactone $3 \mathbf{e}, \mathrm{H}$ could be isolated in $73 \%$ yield, suggesting that the reaction proceeds more smoothly when an electron-donating substituent is present at the site of nucleophilic attack. Consequently, electron-withdrawing substituents should be disadvantageous for the reaction; the para-methoxycarbonylphenyl substituted cyclic sulfite (2b) gave a total yield of lactones $(\mathbf{3 b}, \mathrm{H}$ and $4 \mathrm{~b}, \mathrm{H})$ of only $15 \%$. The para-chlorophenyl substituted cyclic sulfite $(\mathbf{2 d})$ gave lactones $\mathbf{3 d}, \mathbf{H}$ and $\mathbf{4 d}, \mathrm{H}$ in $68 \%$ yield. The naphthyl substituted cyclic sulfite $2 \mathrm{c}$ performed poorly pointing to steric bulk as another limitation for the reaction. All lactones were formed as a single epimer indicating complete thermodynamic control over the $\mathrm{C}-3$ chiral carbon under the basic reaction conditions. Typically, the cyclic sulfites that performed poorly were less reactive, giving less clean reaction mixtures containing large amounts of ketone 7 .

When trans-1,2-disubstituted cyclic sulfites $\mathbf{2 f}$ and $\mathbf{2 g}$ were employed, only traces of the $\gamma$-lactones $3 \mathbf{f}, \mathrm{H}$ and $3 \mathrm{~g}, \mathrm{H}$ could be isolated (Table 1 ). These lactones were formed as one enantiomer, showing that this process is capable of producing $\gamma$-lactones with three consecutive enantiomerically pure chiral centers albeit in very low yield. The major products were cyclopropanes, $\mathbf{5 f}$ and $5 \mathrm{~g}$, and carbonates $6 \mathrm{f}$ and $\mathbf{6 g}$. The increased formation of cyclopropanes versus $\gamma$-lactones can be explained by the increased steric hindrance induced by the $\beta$-substituent in the primary $\mathrm{S}_{\mathrm{N}} 2$ displacement by dimethyl malonate anion, reducing the rate of formation of monosulfite $\mathbf{8 , H}$. The formation of cyclopropanes from $\mathbf{8 , H}$ is an intramolecular reaction, and will still proceed relatively smoothly compared with the bimolecular reaction even though the intramolecular reaction will also be negatively affected by increased size of the $\beta$-substituent.

The yield of lactones generally increased when dimethyl 2-methylmalonate anion was used as nucleo- phile (Table 1) with the exception of the disubstituted cyclic sulfites where no lactone was formed. For example, with the phenyl substutited cyclic sulfite 2 a the total lactone yield increased to $77 \%$ with an enantiomeric excess greater than $95 \%$ [as determined by ${ }^{1} \mathrm{H}$ NMR spectroscopy using $\operatorname{Eu}(\mathrm{hfc})_{3}$ as the chiral shift reagent]. In all cases where the $\gamma$-lactone $3, \mathrm{Me}$ was formed, $3 R^{*}, 4 R^{*}$ - and $3 S^{*}, 4 R^{*}$-diastereoisomers were formed in ratios ranging from $99: 1$ to $3: 2$ showing that the nucleophilic addition took place with variable diastereoselectivity. The relative stereochemical assignment of the $3 S, 4 S$ and the $3 R, 4 S$-diastereoisomers is based on the ${ }^{1} \mathrm{H}$ NMR chemical shifts of the ester methoxy and the C-3 methyl group. In the $3 S, 4 S$-isomer, the methoxy group is cis to the aryl substituent, and thus located in the deshielding cone of the aryl group with an expected downfield shift. For the $3 R, 4 S$-isomer the C-3 methyl group is located in the deshielding cone with an expected downfield shift, whereas the methoxy group will appear at a normal chemical shift. This effect of the aryl substituent can be observed in $(3 S, 4 S)-3 \mathbf{a}, \mathrm{Me}$ where the $\mathrm{C}-3$ methyl is located at $\delta 1.51$ and the methoxy group at $\delta 3.46$, whereas the corresponding chemical shift in the $3 R .4 S$ isomer is $\delta 1.05$ and $\delta 3.78$, respectively. These conclusions are supported by difference NOE-experiments with irradiation of the C-3 methyl group and comparing these NOE results with the internuclear distances calculated for the global minimum for 3d,Me (Table 2).

The decarboxylation reaction of $3, \mathrm{Me}$ to $4, \mathrm{Me}$ takes place via a planar enol intermediate. This allows the conformation with the lowest energy to be formed and the trans product is expected. The formation of trans products is supported by comparing the observed NOE and the measured coupling constant ${ }^{43}$ between $\mathrm{H} 3$ and $\mathrm{H} 4\left(J_{3,4}\right)$ with the internuclear distances and the calculated coupling constant (as determined by MacroModel V5. $0^{44}$ ) for 4 d, Me (see Table 3 and Fig. 1).

Formation of carbonates. The formation of cyclic carbonates 6 , with retention of the $\mathrm{C}-4$ stereochemistry was puzzling. There was evidence that the carbonate carbon originated from the malonate as reactions performed without dimethylmalonate showed no carbonate formation. In these reactions, however, decomposition of the cyclic sulfite to the corresponding diol took place. We have previously described how cyclic sulfites show ambident electrophilic properties towards different nucleo-

Table 2. Comparative examination of NOE and internuclear distances for the two diastereomeric compounds of 3d,Me.

\begin{tabular}{|c|c|c|c|c|}
\hline & \multicolumn{2}{|c|}{$3 R, 4 R\left(E=-133.1 \mathrm{~kJ} \mathrm{~mol}^{-1}\right)^{a}$} & \multicolumn{2}{|c|}{$3 S, 4 R\left(E=-132.4 \mathrm{~kJ} \mathrm{~mol}^{-1}\right)^{a}$} \\
\hline & NOE (\%) & Distance $/ \AA^{b}$ & NOE (\%) & Distance $/ \AA^{b}$ \\
\hline $\begin{array}{l}\text { Me to } \mathrm{Ph}-\mathrm{oH} \\
\text { Me to } \mathrm{H} 4 \\
\text { Me to } \mathrm{H} 5\end{array}$ & $\begin{array}{l}1.66 \\
8.44 \\
-\end{array}$ & $\begin{array}{l}2.92 \text { and } 5.24 \\
2.59 \\
4.41 \text { and } 4.43\end{array}$ & $\begin{array}{l}1.99 \\
2.98 \\
2.67\end{array}$ & $\begin{array}{l}4.24 \text { and } 4.84 \\
2.60 \\
4.30 \text { and } 3.19\end{array}$ \\
\hline
\end{tabular}

${ }^{a}$ Conformation energy. ${ }^{b}$ From Me-C. 
Table 3. Comparative examination of measured and calculated coupling constants, NOE and internuclear distances for the two diastereomeric compounds of $\mathbf{4 d}, \mathrm{Me}$.

\begin{tabular}{|c|c|c|c|}
\hline & $3 R, 4 S$ & $3 S, 4 S$ & \\
\hline \multirow{4}{*}{ 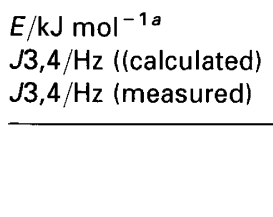 } & -33.1 & -29.3 & \\
\hline & 12.0 & & \\
\hline & 11.7 & & \\
\hline & $\begin{array}{l}\text { NOE } \\
(\%)\end{array}$ & $\begin{array}{l}\text { Distance/ } \\
\AA^{b}\end{array}$ & $\begin{array}{l}\text { Distance/ } \\
\AA^{b}\end{array}$ \\
\hline $\mathrm{Me}$ to $\mathrm{Ph}-\mathrm{oH}$ & 0.69 & 3.96 and 4.19 & 3.66 and 3.73 \\
\hline $\mathrm{Me}$ to $\mathrm{H} 3$ & 7.30 & 2.18 & 2.17 \\
\hline $\mathrm{Me}$ to $\mathrm{H} 4$ & 5.40 & 2.64 & 3.12 \\
\hline
\end{tabular}

${ }^{a}$ Conformation energy. ${ }^{b}$ From Me-C.

philes. ${ }^{45}$ In the reaction between cyclic sulfites and chloride ions the chloride ion can react either at carbon, liberating the sulfite monoester as a leaving group in a normal $\mathrm{S}_{\mathrm{N}} 2$ process, or react at sulfur, liberating an alkoxy ion as the leaving group. ${ }^{45}$ If the malonate anions follow a similar pattern of reactivity a nucleophilic attack on sulfur as shown in Scheme 2 can be envisioned as a competing reaction to the $\mathrm{S}_{\mathrm{N}} 2$ reaction on carbon leading to the $\gamma$-lactone as described above. The nucleophile attacking the sulfite sulfur atom is not neccessarily a malonate enolate ion; hydroxide or hydride ions could also add to the sulfur atom leading to ring-opening and sulfite decomposition. When dimethyl malonate or dimethyl 2-methylmalonate are present, the liberated alkoxy ion can then transesterify the malonate and liberate the sulfinate ion by hydrolysis. A second acyl substitution on the mixed malonate ester can then yield a carbonate and an ester enolate as shown in Scheme 2.

This hypothesis was tested by performing the reaction with dimethyl 2,2-dimethylmalonate. This malonate, which is devoid of nucleophilic properties, can only react after an external nucleophile has ring opened the cyclic sulfite, but should otherwise follow the general scheme for carbonate formation as shown in Scheme 2 . Gratifyingly, the reaction between cyclic sulfite $\mathbf{2 a}$ and dimethyl 2,2-dimethylmalonate gave more carbonate $6 \mathbf{a}$ than did dimethyl 2-methylmalonate and dimethyl malonate. In the disubstituted cyclic sulfites the formation of carbonates is much more pronounced; treatment of sulfite $2 \mathbf{f}$ gives carbonate $\mathbf{6 f}$ in $31 \%$ yield. This effect can be attributed to the increased steric bulk of the sulfite substrate, leading to a shift in selectivity from the more hindered benzylic carbon to the less encumbered sulfite sulfur atom, resulting in carbonate formation.

Reactions with ethyl acetoacetate and ethyl 2-methylacetoacetate enolates. In contrast with reactions between cyclic sulfites and malonate enolates, no $\gamma$-lactone was formed when cyclic sulfite 2a was treated with the enolate generated from ethyl acetoacetate (Scheme 3). The main product in this reaction was acetoxy ester 11a together with two diastereoisomers of dioxolane 12a and small amounts of carbonate $\mathbf{6 a}$ ( Table 4). A tentative rationale for the formation of the acetoxy ester is given in Scheme 4 . The reaction sequence starts with a nucleophilic substitution of the acetoacetate enolate on the benzylic carbon of the cyclic sulfite. The resulting monosulfite anion is then hydrolysed and the liberated alkoxide is then added to the more electrophilic ketone carbonyl rather than to the less electrophilic ester as in the analogous reaction with the malonate enolates. After the addition to the ketone a retro-Claisen condensation sequence takes place giving the acetoxy ester 11. When 11 is treated with dilute acid $\gamma$-lactone 4 is formed in quantitative yield.

The trans-disubstituted cyclic sulfites $\mathbf{2 f}$ and $\mathbf{2 g}$ gave product mixtures in which acetoxy esters $11 \mathrm{f}$ and $11 \mathrm{~g}$ were present in smaller amounts and products originating from $S$-nucleophilicity, $\mathbf{6 f} / \mathbf{6 g}$ and $\mathbf{1 2 f} / \mathbf{1 2 g}$ were more

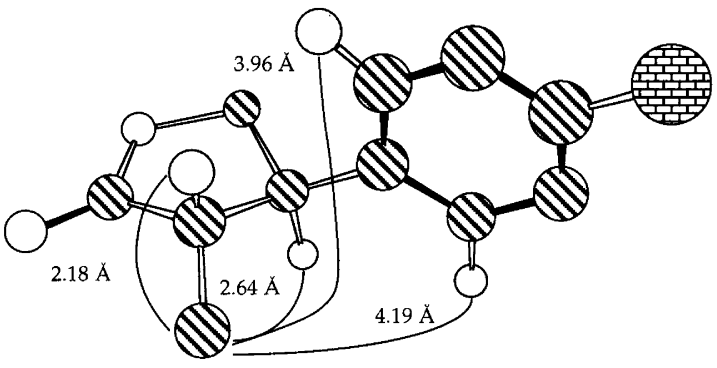

$(3 R, 4 S)-4 \mathrm{~d}, \mathrm{Me}$

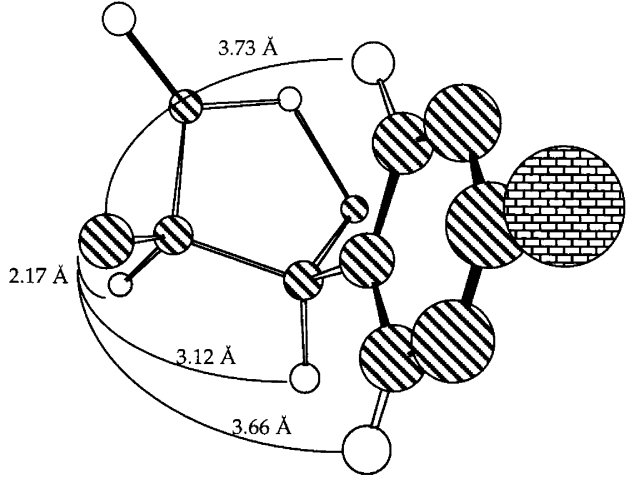

$(3 S, 4 S)-4 d, M e$ 


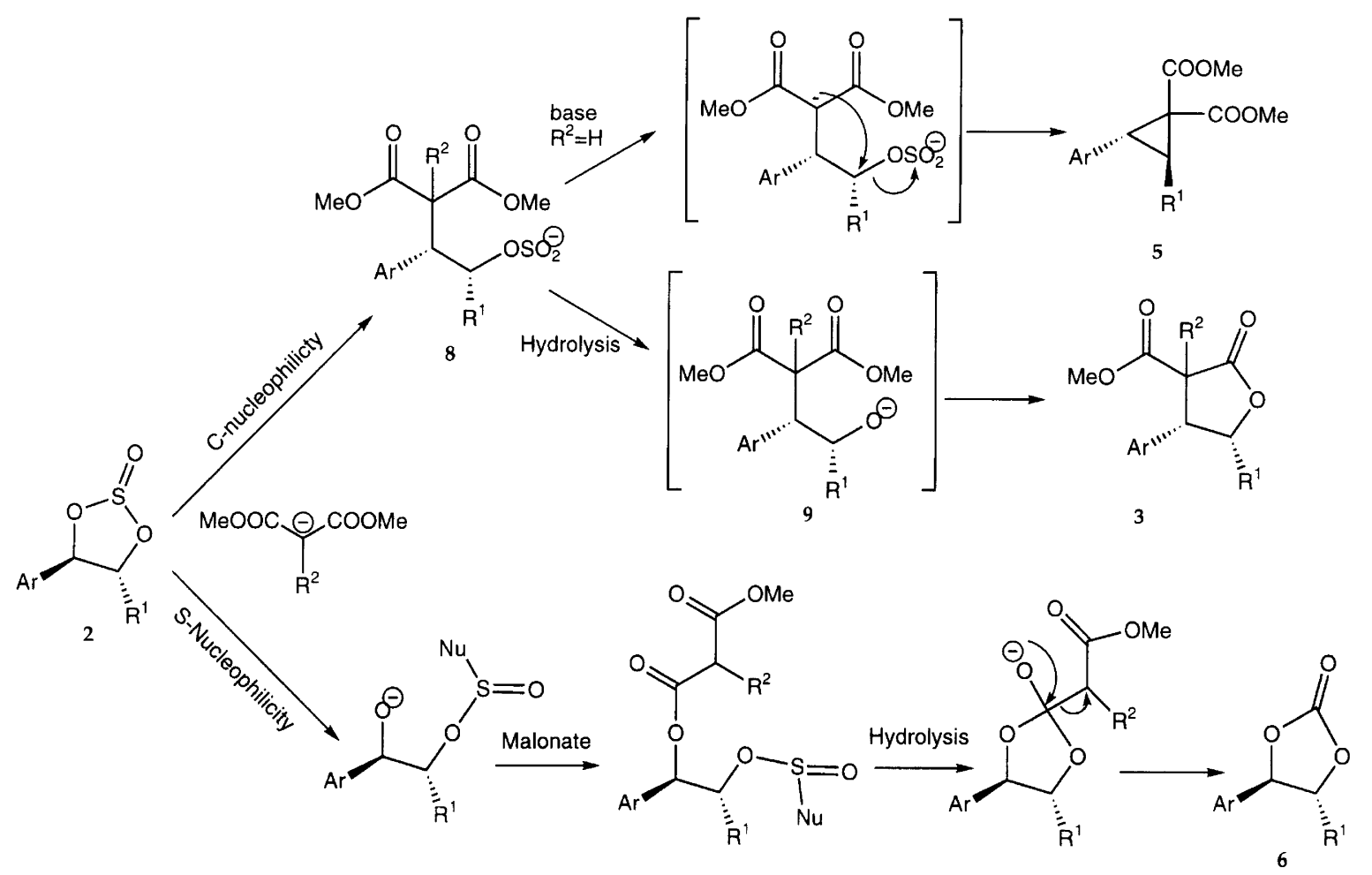

Scheme 2.

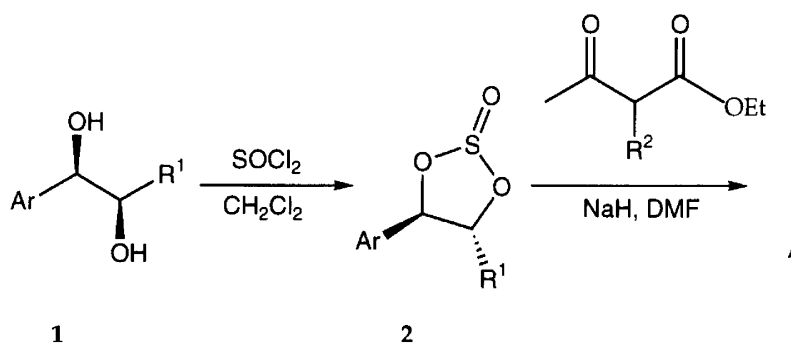<smiles>O=C1O[C@H]([TeH])[C@@H]([TeH])O1</smiles>

6<smiles>[Z17][C@@H]1[C@@H]([Te])C1([C])C(=O)OCC</smiles>

7

$$
\begin{aligned}
& \mathrm{R}^{1}=\mathrm{H}, \mathrm{Me} \\
& \mathrm{R}^{2}=\mathrm{H}, \mathrm{Me}
\end{aligned}
$$<smiles>[R]C(C(=O)OCC)[C@@H]([18OH])[C@@H]([2H])OC(C)=O</smiles>

11<smiles>[R]C(C(=O)OCC)C1(C)O[C@@H]([Te])[C@@H]([R7])O1</smiles>

12

Scheme 3.

pronounced. As was the case for the reactions with malonate anion, this effect can be connected to the increased bulk of the sulfite substrate leading to a shift in nucleophile selectivity to the less encumbered sulfite sulfur atom rather than the carbon atom.

The unusual mechanism for the dioxolane formation 12 (Scheme 4) is sustantiated by hydrolysis of the two diastereomers $12 \mathrm{~g}$. The diol product formed turned out to be a diastereomer of diol $\mathbf{2 g}$ which proved that the dioxolane was formed by an inversion at the secondary carbon atom.

When cyclic sulfite $\mathbf{2 a}$ was treated with ethyl 2-methylacetoacetate three groups of stereoisomeric products appeared: ethyl $(2 R / S, 3 R)$-4-acetoxy-3-phenyl-2-methylbutyrate (11a,Me), (4R)-4,5-dihydro-3-methyl-4-phenyl$2(3 H)$-furanone $(\mathbf{4 a}, \mathrm{Me})$ originating from $\mathrm{C}-\mathrm{C}$ cleavage between $\mathrm{C} 2$ and $\mathrm{C} 3$ in the acetoacetate, and a diastereomeric mixture of dioxolanes 2-(1-ethoxycarbonylethyl)- 
Table 4. Product distribution from the reaction between cyclic sulfites and ethyl acetoacetate or ethyl 2-methylacetoacetate anions.

\begin{tabular}{|c|c|c|c|c|c|c|c|c|c|c|}
\hline \multirow[b]{2}{*}{ No. } & \multicolumn{2}{|c|}{ Substrate } & \multirow{2}{*}{$\frac{\text { Reagent }}{R^{2}}$} & \multicolumn{7}{|c|}{ Yield of products } \\
\hline & $\mathrm{Ar}$ & $\mathrm{R}^{1}$ & & 2 & 4 & 6 & 7 & 10 & 11 & 12 \\
\hline $\begin{array}{l}\mathrm{a}, \mathrm{H} \\
\mathrm{a}, \mathrm{Me}\end{array}$ & $\mathrm{Ph}$ & $\mathrm{H}$ & $\begin{array}{l}\mathrm{Hnt} \\
\mathrm{Me}\end{array}$ & 2 & $\begin{array}{l}1 \\
7\end{array}$ & 1 & 2 & 2 & $\begin{array}{l}70 \\
24+43^{a}\end{array}$ & $\begin{array}{l}18+10^{a} \\
10+7+7^{a}\end{array}$ \\
\hline$f$ & $\mathrm{Ph}$ & $\mathrm{Ph}$ & $\mathrm{H}$ & 26 & & 29 & 19 & 3 & 6 & $3+5^{a}$ \\
\hline $\mathbf{g}$ & $\mathrm{Ph}$ & $\mathrm{Me}$ & $\mathrm{H}$ & 9 & $8+1^{a}$ & 19 & 14 & 1 & 8 & $11+11^{a}$ \\
\hline
\end{tabular}

${ }^{a}$ Diastereomeric mixture.

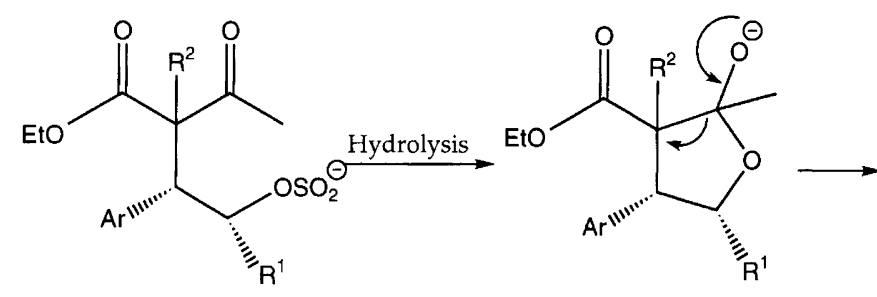<smiles>CCOC(=O)C=C(C)[C@@H](C)OC(C)=O</smiles><smiles>[R7]C(C(C)=O)C(=O)OCC</smiles><smiles>[R]C1C(=O)O[C@@H]([Tl])[C@@H]1[TeH]</smiles>

$\mathrm{R}^{1}=\mathrm{H}, \mathrm{Me}, \mathrm{Ph}$ $\mathrm{R}^{2}=\mathrm{H}, \mathrm{Me}$.<smiles>[Z][C@@H]1O[C@@H](C)[C@@H](C)OS(=O)C1([R])C(=O)OCC</smiles>

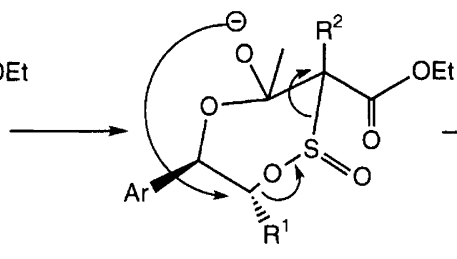

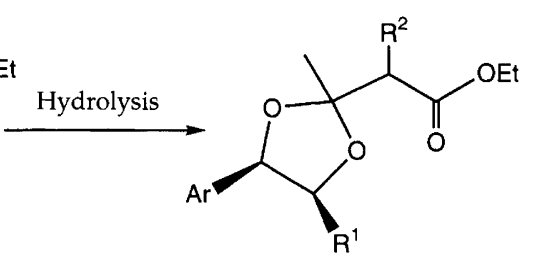

12

Scheme 4.

2-methyl-4-phenyl-1,3-dioxolane (12a,Me) originating from $S$-nucleophilicity.

\section{Conclusions}

Our work shows that chiral cyclic sulfites undergo $\mathrm{S}_{\mathrm{N}} 2$ displacements by soft carbon nucleophiles forming enantiomerically pure $\gamma$-lactones and acetoxy esters. It also shows that if the cyclic sulfites are $\beta$-substituted, the increased steric bulk of the sulfite substrate leads to a shift in regioselectivity to the less encumbered sulfite sulfur, yielding carbonates and dioxolanes. In several cases, formation of cyclopropanes by double $\mathrm{S}_{\mathrm{N}} 2$ displacement can be observed.

\section{Experimental}

General. Proton NMR spectra were recorded on a Jeol Eclipse 400 (399.65 MHz) or PMX 60SI (60 MHz) spectrometer and $\mathrm{CDCl}_{3}$ was used as the solvent unless otherwise stated. The chemical shifts are reported in ppm downfield from $\mathrm{Me}_{4} \mathrm{Si}$.

Gas chromatography was performed on a Varian 3400 gas chromatograph equipped with a Supelco SPB 5 capillary column $(15 \mathrm{~m} \times 0.32 \mathrm{~mm}$ ID).

Combined gas chromatography-mass spectrometry was carried out on a Hewlett Packard 5890 Series II gas chromatograph equipped with either a Supelco SPB $5(25 \mathrm{~m} \times 0.25 \mathrm{~mm}$ ID) or a $\beta$-cyclodextrin $(50 \mathrm{~m} \times 0.25 \mathrm{~mm}$ ID) column connected to a VG 
Analytical Tribrid mass spectrometer. The mass spectra were recorded using EI ionisation $(70 \mathrm{eV})$ and the ion source temperature was $180^{\circ} \mathrm{C}$. CI ionisation was performed with isobutane as the reactant gas and the ion source temperature was $150{ }^{\circ} \mathrm{C}$.

Preparation of diols $\mathbf{l a}-\boldsymbol{d}, \mathbf{l f}$ and $\mathbf{1 g}$. The diols $\mathbf{1 a - d}$; $1 \mathbf{f}$ and $1 \mathrm{~g}$ were prepared in yields ranging from 61 to $80 \%$ from the corresponding alkenes according to literature procedures $^{41.43}$ using (DHQD) ${ }_{2}$-PHAL (to give the $R$ isomer) or (DHQ) $)_{2}-\mathrm{PHAL}$ (to give the $S$ isomer) as a chiral ligand. Enantiomeric purities were usually above $99.9 \%$ (GC).

Preparation of (R)-1-(4-methoxyphenyl)-1,2-ethanediol (1e). The title compound was prepared according to literature procedures ${ }^{41,43}$ using (DHQD) ${ }_{2}$-PHAL, in $61 \%$ yield and the enantiomeric purity was better than $99.9 \%$ (GC). 1e: ${ }^{1} \mathrm{H}$ NMR (400 MHz): $\delta 2.35$ (1 H, br s), 2.75 ( $1 \mathrm{H}$, br s), $3.66(2 \mathrm{H}, \mathrm{m}), 3.80(3 \mathrm{H}, \mathrm{s}), 4.74(1 \mathrm{H}, \mathrm{m})$, $6.85(2 \mathrm{H}, \mathrm{d}, J=8.4 \mathrm{~Hz}), 7.25(2 \mathrm{H}, \mathrm{d}, J=8.4 \mathrm{~Hz}) . \mathrm{MS}$ [m/z (\% rel. int.)]: $168(2, M), 150(15), 137(16), 121$ (100). $[x]_{\mathrm{D}}^{20}-39$ (c 1.0. EtOH).

General procedure for the preparation of cyclic sulfites. The cyclic sulfites $\mathbf{2 a}-\mathbf{d}, \mathbf{2} \mathbf{f}$ and $\mathbf{2 g}$ were prepared in yields ranging from 74 to $99 \%$ from the corresponding diols according to literature procedures. ${ }^{39}$

Preparation of (R)-1-(4-methoxyphenyl)-1,2-ethanediol cyclic sulfite [( R)-4-(4-methoxyphenyl)-1,3,2-dioxathiolan-2-one] (2e). The title compound was prepared from diol 1e in accordance with the literature procedure ${ }^{39}$ except that the reaction temperature was $-78^{\circ}$, and 4 equiv. of triethylamine were present. The yield was $99 \%$.

2e: ${ }^{1} \mathrm{H}$ NMR (400 MHz): $\delta 3.81(3 \mathrm{H}, \mathrm{s}), 4.15[1 / 2 \mathrm{H}$, dd (apparent triplet), $J=8.4 \mathrm{~Hz}], 4.47(1 / 2 \mathrm{H}$, dd, $J=$ $9.2,10.8 \mathrm{~Hz}), 4.67(1 / 2 \mathrm{H}, \mathrm{dd}, J=6.4,9.2 \mathrm{~Hz}), 4.88$ $(1 / 2 \mathrm{H}, \mathrm{dd}, J=6.8,8.4 \mathrm{~Hz}), 5.37(1 / 2 \mathrm{H}, \mathrm{dd}, J=6.4$, $10.8 \mathrm{~Hz}), 5.88(1 / 2 \mathrm{H}, \mathrm{dd}, J=6.8,7.6 \mathrm{~Hz}), 6.92(2 \mathrm{H}, \mathrm{m})$, $7.28(1 \mathrm{H}, \mathrm{d}, J=8.8 \mathrm{~Hz}), 7.41(1 \mathrm{H}, \mathrm{d}, J=8.8 \mathrm{~Hz}) . \mathrm{MS}$ $[\mathrm{m} / z$ (\% rel. int.)]: $214(1, M), 184(0.4), 150(21), 135$ (25), $121(100)$.

Reaction of cyclic sulfites with malonate anion - general procedure. Sodium hydride $(0.36 \mathrm{~g}$ of a $20 \%$ suspension, $3.0 \mathrm{mmol}$ ) was washed four times with petroleum ether (b.p. $40-60^{\circ} \mathrm{C}$ ) under dry nitrogen, dry DMF $(4 \mathrm{ml})$ was added and the resulting slurry was cooled in an ice bath. Dimethyl malonate $(0.40 \mathrm{~g}, 3.0 \mathrm{mmol})$ or dimethyl 2-methylmalonate $(0.44 \mathrm{~g}, 3.0 \mathrm{mmol})$ was added and the reaction mixture was stirred for a few minutes after the gas had evolved. The cyclic sulfite $(1.0 \mathrm{mmol})$ was added and the reaction mixture was stirred with heating $\left(70-80^{\circ} \mathrm{C}\right)$. The reaction was monitored by GC. The reaction was quenched by addition of sulfuric acid ( $20 \%$, $5 \mathrm{ml})$. The resulting mixture was extracted with ethyl acetate $(2 \times 10 \mathrm{ml})$ and the combined organic phases were washed with sulfuric acid $(20 \%, 5 \mathrm{ml})$, water $(2.5 \mathrm{ml})$, saturated sodium hydrogencarbonate solution $(2 \times 2.5 \mathrm{ml})$ and brine $(5 \mathrm{ml})$ before being dried $\left(\mathrm{MgSO}_{4}\right)$. The products were separated by flash chromatography $\left(\mathrm{SiO}_{2} ; 20 \%\right.$ EtOAc in $n$-heptane).

Reaction of cyclic sulfite S-2a with dimethyl malonate anion. The reaction was performed as described in the general procedure and the reaction time was $4.5 \mathrm{~h}$. The $\gamma$-lactone, $(3 S, 4 R)-4,5$-dihydro-3-methoxycarbonyl-4-phenyl-2(3H)furanone $(3 \mathbf{a}, \mathrm{H})$ was isolated.

3a,H: ${ }^{1} \mathrm{H}$ NMR (400 MHz): $\delta 3.76(1 \mathrm{H}, \mathrm{d}, J=9.7 \mathrm{~Hz})$, $3.79(3 \mathrm{H}, \mathrm{s}), 4.22(1 \mathrm{H}, \mathrm{m}, J=7.6 \mathrm{~Hz}), 4.28(1 \mathrm{H}, \mathrm{t}, J=$ $8.3 \mathrm{~Hz}), 4.72(1 \mathrm{H}, \mathrm{t}, J=8.3 \mathrm{~Hz}), 7.3(5 \mathrm{H}, \mathrm{m}) .{ }^{13} \mathrm{C}$ NMR (100.5 MHz): $\delta 45.21,53.14,53.31,72.38,126.90,128.23$, 129.31, 138, 167.51, 171.11. MS [ $m / z$ (\% rel. int.)]: EI, $220(9, M), 189$ (10), 176 (46), 175 (100), 161(87), 145 (35), 131 (83). The enantiomeric purity was better than $95 \%$ as determined by ${ }^{1} \mathrm{H}$ NMR spectroscopy using $\mathrm{Eu}(\mathrm{hfc})_{3}$ as a chiral shift reagent and benzene- $d_{6}$ as the solvent.

Two additional products were tentatively identified by combined GC-MS: dimethyl (2S)-2-phenylcyclopropane-1,1-dicarboxylate (5a) and (4S)-4-phenyl-1,3dioxolan-2-one (6a).

5a: MS $[m / z$ (\% rel. int.)]: EI, $234(8, M), 202$ (34), 171 (40), 170 (80), 143 (12), 129 (12), 121 (99), 115 (100).

6a: MS $[m / z$ (\% rel. int.)]: EI, $164(61, M), 120(9)$, 119 (11), 105 (25), 91 (64), 90 (100).

Reaction of cyclic sulfite $\mathrm{S}-\mathbf{2} \boldsymbol{b}$ with dimethyl malonate anion. The reaction was performed as described in the general procedure and the reaction time was $24 \mathrm{~h}$. Three products were isolated: 1-(4-methoxycarbonylphenyl)-1-ethanone, $(3 R / S, \quad 4 R)-4,5$-dihydro-3-methoxycarbonyl-4-(4-methoxycarbonylphenyl)-2(3H)-furanone $(3 \mathrm{~b}, \mathrm{H})$ and $(4 S)-4$ (4-methoxycarbonylphenyl)-1, 3-dioxolan-2-one(6b).

3b,H: ${ }^{1} \mathrm{H}$ NMR (400 MHz): $\delta 3.74(1 \mathrm{H}, \mathrm{m}), 3.80$ (3 H, s), $3.91(3 \mathrm{H}, \mathrm{s}), 4.29(2 \mathrm{H}, \mathrm{m}), 4.75(1 \mathrm{H}, \mathrm{m}), 7.32$ $(2 \mathrm{H}, \mathrm{d}, J=8.0 \mathrm{~Hz}), 8.05(2 \mathrm{H}, \mathrm{d}, J=8.0 \mathrm{~Hz}) .{ }^{13} \mathrm{C} \mathrm{NMR}$ (100.5 MHz): $\delta 45.1,52.4,53.1,53.4,125.6,127.1,130.6$, $142.1,166.4,167.3,170.8$. MS [m/z (\% rel. int.)]: EI, 220 (23), 189 (20), 162 (100), 131 (85), 103 (16). CI, 279 $(100, M+\mathrm{H})$.

6b: ${ }^{1} \mathrm{H}$ NMR (400 MHz): $\delta 3.93(3 \mathrm{H}, \mathrm{s}), 4.28(1 \mathrm{H}$, $\mathrm{t}, J=8.0 \mathrm{~Hz}), 4.84(1 \mathrm{H}, \mathrm{t}, J=8.4 \mathrm{~Hz}), 5.74(1 \mathrm{H}, \mathrm{t}, J=$ $8.0 \mathrm{~Hz}), 7.33(2 \mathrm{H}, \mathrm{d}, J=8.8 \mathrm{~Hz}), 8.10(2 \mathrm{H}, \mathrm{d}, J=$ $8.8 \mathrm{~Hz})$. MS $[m / z(\%$ rel. int.)]: EI, $222(22, M), 191$ (100), $163(14), 133(30), 105(36)$. CI, $223(100, M+\mathrm{H})$.

Reaction of cyclic sulfite S-2c with dimethyl malonate anion. The reaction was performed as described in the general procedure and the reaction time was 3 days. Three products were isolated: $(3 S, 4 R)-4,5$-dihydro-3-methoxycarbonyl-4-(2-naphthyl)-2( $3 H)$-furanone $(3 \mathbf{c}, \mathrm{H}),(4 R)$ 4,5-dihydro-4-(2-naphthyl)-2(3H)-furanone $(\mathbf{4 c}, \mathrm{H})$ and (4S)-4-(2-naphthyl)-1,3-dioxolan-2-one (6c). 
3c,H: ${ }^{1} \mathrm{H}$ NMR (400 MHz): $\delta 3.81(3 \mathrm{H}, \mathrm{s}), 3.85(1 \mathrm{H}$, d, $J=10.3 \mathrm{~Hz}), 4.39(2 \mathrm{H}, \mathrm{m}), 4.81(1 \mathrm{H}, \mathrm{m}), 7.34-7.90$ $(7 \mathrm{H}, \mathrm{m}) . \mathrm{MS}[\mathrm{m} / z$ (\% rel. int.)]: EI, $212(57), 165$ (3), 154 (100), 141 (6), 128 (7). CI, $271(100, M+\mathrm{H})$.

4c,H. MS $[m / z$ (\% rel. int.)]: EI, $212(55, M), 165$ (3), 154 (100), 141 (7), 115 (6). CI, $213(100, M+\mathrm{H})$.

6c: ${ }^{1} \mathrm{H}$ NMR $(400 \mathrm{MHz}): \delta 4.44(1 \mathrm{H}, \mathrm{t}, J=8.3 \mathrm{~Hz})$, $4.87(1 \mathrm{H}, \mathrm{t}, J=8.3 \mathrm{~Hz}), 5.84(1 \mathrm{H}, \mathrm{t}, J=7.8 \mathrm{~Hz}), 7.51$ $(3 \mathrm{H}, \mathrm{m}), 7.92(4 \mathrm{H}, \mathrm{m})$. MS [m/z (\% rel. int.)]: EI, 214 (93, M), 170 (19), 165 (20), 154 (28), 141 (100), 128 (46), 115 (32).

Reaction of cyclic sulfite $\mathrm{R}-\mathbf{2 d}$ with dimethyl malonate anion. The reaction was performed as described in the general procedure and the reaction time was $4.5 \mathrm{~h}$. Four products were identified: ( $3 R, 4 S)-4,5$-dihydro-3-methoxycarbonyl4-(4-chlorophenyl)-2(3H)-furanone $(3 \mathrm{~d}, \mathrm{H}),(4 S)$-4,5-dihydro-4-(4-chlorophenyl)-2(3H)-furanone $(\mathbf{4 d}, \mathrm{H})$, dimethyl (2R)-2- (4-chlorophenyl)-cyclopropane-1,1-dicarboxylate(5d) and (4R)-4-(4-chlorophenyl)-1,3-dioxolan-2-one (6d).

3d,H: ${ }^{1} \mathrm{H}$ NMR $(400 \mathrm{MHz}): \delta 3.69(1 \mathrm{H}, \mathrm{d}, J=$ $10.2 \mathrm{~Hz}), 3.78$ ( $3 \mathrm{H}, \mathrm{s}), 4.21(2 \mathrm{H}, \mathrm{m}), 4.69(1 \mathrm{H}, \mathrm{m}), 7.18$ $(2 \mathrm{H}, \mathrm{d}, J=8.8 \mathrm{~Hz}), 7.33(2 \mathrm{H}, \mathrm{d}, J=8.8 \mathrm{~Hz}) .{ }^{13} \mathrm{C}$ NMR (100.5 MHz): $\delta 44.67,53.25,53.39,72.13,128.47,129.57$, $134.24,135.1,167.34,171.0$. MS $[m / z$ (\% rel. int.)]: EI, $256(10, M), 254(26, M), 225$ (3.5), 223 (11), 212 (24), 211 (67), 210 (69), 209 (100), 198 (12), 197 (43), 196 (37), 195 (93), 181 (21), 179 (57), 167 (51), 165 (92), 151 (23), 149 (33).

4d,H: MS $[m / z$ (\% rel. int.)]: EI, $198(8, M), 196(22$, $M), 140$ (32), 138 (100), 127(2), 125 (6), 103 (155).

5d: ${ }^{1} \mathrm{H}$ NMR $(400 \mathrm{MHz}): \delta 1.73(1 \mathrm{H}, \mathrm{dd}, J=5.5$, $9.12 \mathrm{~Hz}), 2.15(1 \mathrm{H}, \mathrm{dd}, J=5.1,8.0 \mathrm{~Hz}), 3.17(1 \mathrm{H}, \mathrm{t}$, $J=8.8 \mathrm{~Hz}), 3.40(3 \mathrm{H}, \mathrm{s}), 3.78(3 \mathrm{H}, \mathrm{s}), 7.12(2 \mathrm{H}, \mathrm{d}, J=$ $8.4 \mathrm{~Hz}), 7.23(2 \mathrm{H}, \mathrm{d}, J=8.4 \mathrm{~Hz})$. MS [ $m / z$ (\% rel. int.)]: EI, $270(6, M), 268(18, M), 238(19), 236(56), 206$ (36), 204 (96), 157 (35), 155 (100), 151 (23), 149 (62). 6d: MS $[m / z$ (\% rel. int.)]: EI, $200(23, M), 198(38, M)$, 156 (5), 154 (15), 127 (29), 126 (37), 125 (87), 124 (100).

Reaction of cyclic sulfite R-2e with dimethyl malonate anion. The reaction was performed as described in the general procedure except that THF was the solvent. The reaction time was $24 \mathrm{~h}$. Two products were isolated: $(3 R, 4 S)$ 4,5-dihydro -3 -methoxycarbonyl -4-(4-methoxyphenyl) $2(3 H)$-furanone $(3 e, H),(4 S)-4,5$-dihydro-4-(4-methoxyphenyl)-2(3H)-furanone $(4 \mathrm{e}, \mathrm{H})$.

3e,H: ${ }^{1} \mathrm{H}$ NMR $(400 \mathrm{MHz}): \delta 3.68(1 \mathrm{H}, \mathrm{d}, J=$ $10.3 \mathrm{~Hz}), 3.77(3 \mathrm{H}, \mathrm{s}), 3.78(3 \mathrm{H}, \mathrm{s}), 4.10-4.25(2 \mathrm{H}, \mathrm{m})$, $4.66(1 \mathrm{H}, \mathrm{t}, J=8.0 \mathrm{~Hz}), 6.88(2 \mathrm{H}, \mathrm{d}, J=8.4 \mathrm{~Hz}), 7.15$ $(2 \mathrm{H}, \mathrm{d}, J=8.8 \mathrm{~Hz}) \cdot{ }^{13} \mathrm{C}$ NMR $(100.5 \mathrm{MHz}): \delta 44.71$, $53.23,53.55,55.41,72.59,114.72,128.16,128.75,159.50$, 167.66, 171.42. MS $[m / z$ (\% rel. int.)]: EI, $250(51, M)$, 219 (9), 206 (52), 190 (60), 175 (48), 161 (100), 132 (58).

4e,H: MS $[m / z$ (\% rel. int.)]: EI, $192(37, M), 134$ (100), 121 (17), 119 (18).
Reaction of cyclic sulfite S-2f with dimethyl malonate anion. The reaction was performed as described in the general procedure, but a higher temperature $\left(90-100^{\circ} \mathrm{C}\right)$ and 9 equiv. of sodium hydride and dimethyl malonate were used. The reaction time was 2 days. Two products were identified: dimethyl $(2 S, 3 S)$-2,3-diphenylcyclopropane1,1-dicarboxylate (5f) and (4S,5S)-4,5-diphenyl-1,3dioxolan-2-one (6f).

5f: ${ }^{1} \mathrm{H}$ NMR was in accordance with the literature. ${ }^{46}$ MS [ $m / z$ (\% rel. int.)]: EI, $310(1, M), 278$ (62), 246 (100), 218 (23), 191 (76).

6f: ${ }^{1} \mathrm{H}$ NMR (60 MHz): $\delta 5.45(2 \mathrm{H}, \mathrm{s}), 7.4(10 \mathrm{H}, \mathrm{m})$. MS $[m / z$ (\% rel. int.)]: EI, $240(38, M), 196(20), 195$ (31), 178 (16), 167 (65), 90 (100).

Reaction of cyclic sulfite RR-2 $g$ with dimethyl malonate anion. The reaction was performed as described in the general procedure, but a higher temperature $\left(90-100^{\circ} \mathrm{C}\right)$ and 9 equiv. of sodium hydride and dimethyl malonate were used. The reaction time was 3 days. Three products were isolated: $(3 R / S, 4 S, 5 R)-4,5$-dihydro-3-methoxycarbonyl-5-methyl-4-phenyl-2(3H)-furanone $(3 \mathrm{~g}, \mathrm{H})$, dimethyl (2S,3R)-2-methyl-3-phenylcyclopropane-1,1-dicarboxylate (5g) and $(4 R, 5 R)$-5-methyl-4-phenyl-1,3-dioxolan-2-one (6g).

3g,H: ${ }^{1} \mathrm{H}$ NMR (400 MHz): $\delta 1.02(3 \mathrm{H}, \mathrm{d}, J=6.3 \mathrm{~Hz}$ ), $3.81(3 \mathrm{H}, \mathrm{s}), 3.95(1 \mathrm{H}, \mathrm{d}, J=8.3 \mathrm{~Hz}), 4.21(1 \mathrm{H}, \mathrm{t}, J=$ $7.3 \mathrm{~Hz}), 5.07(1 \mathrm{H}, \mathrm{m}), 7.14-7.45(5 \mathrm{H}, \mathrm{m})$. MS $[\mathrm{m} / z(\%$ rel. int.)]: EI, $234(2, M), 190$ (29), 175 (8), 162 (95), 161 (27), 131 (100).

5g: The ${ }^{1} \mathrm{H}$ NMR data is in accordance with the literature. ${ }^{47}$ MS $[m / z$ (\% rel. int.)]: EI, $248(20, M), 233$ (8), 216 (21), 188 (23), 185 (48), 184 (81), 129 (87), $121(100)$.

6g: ${ }^{1} \mathrm{H}$ NMR (400 MHz): $\delta 1.57(3 \mathrm{H}, \mathrm{d}, J=5.9 \mathrm{~Hz})$, $4.61(1 \mathrm{H}, \mathrm{dq}, J=5.9,8.3 \mathrm{~Hz}), 5.13(1 \mathrm{H}, \mathrm{d}, J=8.3 \mathrm{~Hz})$, $7.32(5 \mathrm{H}, \mathrm{m})$. MS $[m / z(\%$ rel. int.)]: EI, $178(54, M)$, 133 (30), 117 (6), 105 (63), 90 (100).

Reaction of cyclic sulfite S-2a with dimethyl 2-methylmalonate anion. The reaction was performed as described in the general procedure except that the reaction temperature was $60^{\circ} \mathrm{C}$. The reaction time was $24 \mathrm{~h}$. The $\gamma$-lactones, ( $3 R$ and $3 S, 4 S$ )-4,5-dihydro-3-methoxycarbonyl-3-methyl-4-phenyl-2(3H)-furanone $(3 \mathrm{a}, \mathrm{Me})$ was isolated as a nearly $1: 1$ diastereomeric mixture in addition to a $1: 8$ diastereomeric mixture of $(3 S$ and $3 R, 4 R$ )-4,5-dihydro-3-methyl-4-phenyl-2(3H)-furanone $(4 \mathbf{a}, \mathrm{Me})$ and $(4 S)$-4-phenyl-1,3-dioxolan-2-one (6a).

3a, Me $(3 S, 4 S):{ }^{1} \mathrm{H}$ NMR (400 MHz): $\delta 1.11(3 \mathrm{H}, \mathrm{s})$, $3.84(3 \mathrm{H}, \mathrm{s}), 4.19(1 \mathrm{H}, \mathrm{t}, J=6.6 \mathrm{~Hz}), 4.56(1 \mathrm{H}, \mathrm{dd}, J=$ $6.2,9.2 \mathrm{~Hz}), 4.70(1 \mathrm{H}, \mathrm{dd}, J=6.8,9.2 \mathrm{~Hz}), 7.1-7.35$ $(5 \mathrm{H}, \mathrm{m}) . \mathrm{MS}[\mathrm{m} / \mathrm{z}$ (\% rel. int.)]: EI, $234(55, M), 219$ (1), 203 (8), 189 (3), 175 (10), 158 (87), 131(100), 115 (71). CI, $235(100, M+\mathrm{H})$.

3a, Me $(3 R, 4 S):{ }^{1} \mathrm{H}$ NMR (400 MHz): $\delta 1.57(3 \mathrm{H}, \mathrm{s})$, $3.52(3 \mathrm{H}, \mathrm{s}), 3.64(1 \mathrm{H}, \mathrm{dd}, J=8.0,11.0 \mathrm{~Hz}), 4.57(1 \mathrm{H}$, dd, $J=8.0,8.8 \mathrm{~Hz}), 4.78(1 \mathrm{H}, \mathrm{dd}, J=8.8,11.0 \mathrm{~Hz})$, 
7.1-7.35 (5 H, m). MS [m/z (\% rel. int.)]: EI, $234(2, M)$, 219, (2), 203, (3), 189 (100), 175 (83), 158 (5), 131, (18), 115 (33). CI, $235(100, M+\mathrm{H})$.

4a,Me $(3 R, 4 R):{ }^{1} \mathrm{H}$ NMR $(400 \mathrm{MHz}): \delta 1.26(3 \mathrm{H}, \mathrm{d}$, $J=6.9 \mathrm{~Hz}), 2.73(1 \mathrm{H}, \mathrm{m}), 3.27(1 \mathrm{H}, \mathrm{m}), 4.15(1 \mathrm{H}, \mathrm{dd}$, $J=9.16,10.6 \mathrm{~Hz}), 4.55(1 \mathrm{H}, \mathrm{dd}, J=8.1 \mathrm{H}$ and $9.2 \mathrm{~Hz})$, 7.25-7.40 (5 H, m). ${ }^{13} \mathrm{C}$ NMR $(100.5 \mathrm{MHz}): \delta 13.49$, 41.77, 50.07, 71.80, 127.33, 128.01, 129.24, 138.2, 179.0. MS $[m / z(\%$ rel. int.)]: EI, $176(39, M), 118(100), 91(18)$.

6a: ${ }^{1} \mathrm{H}$ NMR $(400 \mathrm{MHz}): \delta 4.34(1 \mathrm{H}, \mathrm{dd}, J=8.1$, $8.4 \mathrm{~Hz}), 4.80(1 \mathrm{H}, \mathrm{t}, J=8.4 \mathrm{~Hz}), 5.67(1 \mathrm{H}, \mathrm{t}, J=8.1 \mathrm{~Hz})$. ${ }^{13} \mathrm{C}$ NMR $(100.5 \mathrm{MHz}): \delta 53.2,71.22,125.92,129.33$, 129.83, 136. MS [m/z (\% rel. int.)]: EI, $164(65, M), 119$ (12), 105 (25), 91 (100).

Reaction of cyclic sulfite S-2b with dimethyl 2-methylmalonate anion. The reaction was performed as described in the general procedure and the reaction time was $3.5 \mathrm{~h}$. The main product isolated was 1-(4-methoxycarbonylphenyl)-1-ethanone $77 \%$. The minor products were ( $3 R$ and $3 S, 4 S)$-4,5-dihydro-3-methoxycarbonyl-3methyl -4-(4-methoxycarbonylphenyl) -2(3H) -furanone $(\mathbf{3 b}, \mathrm{Me})$, which were isolated in a $1: 9$ diastereomeric mixture.

3b,Me $(3 S, 4 S):{ }^{1} \mathrm{H}$ NMR (400 MHz): $\delta 1.11(3 \mathrm{H}, \mathrm{s})$, $3.86(3 \mathrm{H}, \mathrm{s}) 3.93(3 \mathrm{H}, \mathrm{s}), 4.26(1 \mathrm{H}, \mathrm{m}), 4.58(1 \mathrm{H}, \mathrm{dd}$, $J=5.9,9.3 \mathrm{~Hz}), 4.74(1 \mathrm{H}, \mathrm{dd}, J=7.3,9.3 \mathrm{~Hz}), 7.22(2 \mathrm{H}$, d, $J=8.3 \mathrm{~Hz}), 8.03(2 \mathrm{H}, \mathrm{d}, J=8.3 \mathrm{~Hz})$. MS $[m / z(\%$ rel. int.)]: EI, 292 (43, M), 277 (1), 261 (63), 248 (20), 247 (6), 233 (13), 216 (35), 189 (49), 178 (60), 157 (87), $129(95), 115(100)$.

3b,Me $(3 R, 4 S):{ }^{1} \mathrm{H}$ NMR (400 MHz): $\delta 1.60(3 \mathrm{H}, \mathrm{s})$, $3.53(3 \mathrm{H}, \mathrm{s}), 3.93(3 \mathrm{H}, \mathrm{s}), 4.30(1 \mathrm{H}, \mathrm{m}), 4.61(1 \mathrm{H}, \mathrm{m})$, $4.81(1 \mathrm{H}, \mathrm{dd}, J=9.3,11.2 \mathrm{~Hz}), 7.33(2 \mathrm{H}, \mathrm{d}, J=8.3 \mathrm{~Hz})$, $8.04(2 \mathrm{H}, \mathrm{d}, J=8.3 \mathrm{~Hz})$. MS $[m / z(\%$ rel. int.)]: EI, 292 (2, M), 277 (3), 261 (16), 247 (100), 233 (93), 129 (33), $115(47)$.

Reaction of cyclic sulfite S-2c with dimethyl 2-methylmalonate anion. The reaction was performed as described in the general procedure and the reaction time was 2 days. Three groups of products were isolated: $(3 R, 4 S)$ - and $(3 S, 4 S)$-4,5-dihydro-3-methoxycarbonyl-3-methyl-4-(2naphthyl)-2(3H)-furanone $(3 \mathrm{c}, \mathrm{Me})$ in a $1: 4$ diastereomeric mixture, $(3 R, 4 R)$ - and $(3 S, 4 R)-4,5$-dihydro-4(2-naphthyl)-3-methyl-2(3H)-furanone $(\mathbf{4 c}, \mathbf{M e})$ in a nearly $1: 1$ diastereomeric mixture and $(4 S)-4$ (2-naphthyl)-1,3-dioxolan-2-one (6c).

3c, $\mathrm{Me}(3 S, 4 S):{ }^{1} \mathrm{H}$ NMR $(400 \mathrm{MHz}): \delta 1.15(3 \mathrm{H}, \mathrm{s})$, $3.88(3 \mathrm{H}, \mathrm{s}), 4.35(1 \mathrm{H}, \mathrm{m}), 4.69(1 \mathrm{H}, \mathrm{m}), 4.80(1 \mathrm{H}$, dd, $J=7.3,9.3 \mathrm{~Hz}), 7.2-8.9(7 \mathrm{H}, \mathrm{m})$. MS $[m / z(\%$ rel. int.)]: EI, 284 (48, M), 239 (100), 225 (82), 208 (30), 195 (11), 179 (42), 141 (41).

3c, Me $(3 R, 4 S):{ }^{1} \mathrm{H}$ NMR (400 MHz): $\delta 1.64$ (3 H, s), $3.50(3 \mathrm{H}, \mathrm{s}), 3.79(1 \mathrm{H}, \mathrm{m}), 4.65(1 \mathrm{H}, \mathrm{m}), 4.93(1 \mathrm{H}$, dd, $J=8.8,10.7 \mathrm{~Hz}), 7.2-8.9(7 \mathrm{H}, \mathrm{m})$. MS $[m / z(\%$ rel. int.)]: EI, $284(100, M), 239$ (8), 225 (9), 208 (18), 195 (7), 181 (18), 179 (17), 170 (100), 141 (85).
4c,Me: MS $[m / z(\%$ rel. int.)]: EI, $226(63, M), 212$ (59), 181 (8), 168 (61), 154 (100), 128 (14).

6c: $M S[m / z(\%$ rel. int.)]: EI, $214(75, M), 170$ (22), 154 (45), 141 (100), 128, (40).

Reaction of cyclic sulfite $\mathrm{R}-2 \mathrm{~d}$ with dimethyl 2-methylmalonate anion. The reaction was performed as described in the general procedure and reaction time was $3 \mathrm{~h}$. Three products were isolated: $(3 R, 4 R)$ - and $(3 S, 4 R)-4,5$-dihydro -4 -(4 -chlorophenyl ) -3 -methoxycarbonyl -3 -methyl $2(3 H)$-furanone $(3 d, M e)$ in a $7: 1$ diastereomeric mixture, (3S,4S)-4,5-dihydro-4-(4-chlorophenyl)-3-methyl-2(3H)furanone $(4 d, \mathrm{Me})$ and $(4 R)-4-(4-c h l o r o p h e n y l)-1,3-d i-$ oxolan-2-one (6d)

3d,Me $(3 R, 4 R):{ }^{1} \mathrm{H}$ NMR (400 MHz): $\delta 1.11(3 \mathrm{H}, \mathrm{s})$, $3.84(3 \mathrm{H}, \mathrm{s}), 4.17$ [ $1 \mathrm{H}, \mathrm{dd}$ (apparent triplet), $J=6.8 \mathrm{~Hz}$, $4.51(1 \mathrm{H}, \mathrm{dd}, J=6.0,9.4 \mathrm{~Hz}), 4.69(1 \mathrm{H}, \mathrm{dd}, J=7.1$, $9.3 \mathrm{~Hz}), 7.08(2 \mathrm{H}, \mathrm{m}), 7.32(2 \mathrm{H}, \mathrm{m})$. MS $[\mathrm{m} / \mathrm{z}(\% \mathrm{rel}$. int.)]: EI, $270(2, M), 268$ (6), 225 (33), 223 (100), 211 (26), 209 (78).

3d,Me, $(3 S, 4 R):{ }^{1} \mathrm{H}$ NMR $(400 \mathrm{MHz}): \delta 1.57(3 \mathrm{H}$, s), $3.57(3 \mathrm{H}, \mathrm{s}), 3.59(1 \mathrm{H}, \mathrm{dd}, J=8.0,11.0 \mathrm{~Hz}), 4.57$ ( $1 \mathrm{H}, \mathrm{dd}, J=8.1,9.0 \mathrm{~Hz}), 4.74(1 \mathrm{H}, \mathrm{dd}, J=9.0,11.0 \mathrm{~Hz}$ ), $7.10(2 \mathrm{H}, \mathrm{m}), 7.32(2 \mathrm{H}, \mathrm{m}) . \mathrm{MS}[m / z(\%$ rel. int. $)]$ : EI, $270(15, M), 268(47, M), 139$ (2), 237 (8), 194 (18), 192 (55), 167 (18), $165(55), 156$ (25), 154 (68), 115 (100).

4d,Me $(3 S, 4 S):{ }^{1} \mathrm{H}$ NMR (400 MHz): $\delta 1.19(3 \mathrm{H}, \mathrm{d}$, $J=6.8 \mathrm{~Hz}), 2.62(1 \mathrm{H}, \mathrm{m}), 3.18-3.25(1 \mathrm{H}, \mathrm{m}), 4.04(1 \mathrm{H}$, dd, $J=9.3,10.7 \mathrm{~Hz}), 4.47(1 \mathrm{H}, \mathrm{d}, J=8.8 \mathrm{~Hz}), 7.13(2 \mathrm{H}$, d, $J=8.8 \mathrm{~Hz}), 7.29(2 \mathrm{H}, \mathrm{d}, J=8.8 \mathrm{~Hz})$. MS $[m / z(\%$ rel. int.)]: EI, $212(11, M), 210$ (31), 154 (34), 152 (100), $127(4), 125(12)$.

6d: ${ }^{1} \mathrm{H}$ NMR (400 MHz): $\delta 4.29$ [1 H, dd (apparent triplet), $J=8 \mathrm{~Hz}$ ], $4.79(1 \mathrm{H}, \mathrm{t}, J=8 \mathrm{~Hz}), 5.63(1 \mathrm{H}, \mathrm{t}$, $J=8 \mathrm{~Hz}), 7.29(2 \mathrm{H}, \mathrm{d}, J=8 \mathrm{~Hz}), 7.40(2 \mathrm{H}, \mathrm{d}, J=8 \mathrm{~Hz})$. MS [ $m / z$ (\% rel. int.)]: EI, $200(22, M), 198(67, M)$, 163 (13), 156 (1), $155(2), 154$ (4), 153 (6), 141 (9), 139 (25), 127 (17), $126(36), 125(51), 124(100), 119(21)$, 114 (15), 112 (47), 91 (31), 89 (89).

Reaction of cyclic sulfite R-2e with dimethyl 2-methylmalonate anion. The reaction was performed as described in the general procedure and the reaction time was $3.5 \mathrm{~h}$. Three products were isolated: ( $3 R$ and $3 S, 4 R)$ 4,5-dihydro-3-methoxycarbonyl-4-(4-methoxyphenyl)-3methyl-2(3H)-furanone (3e,Me) in a $2: 1$ diastereomeric mixture and $(3 S, 4 S)-4,5$-dihydro-4-(4-methoxyphenyl)3-methyl-2(3H)-furanone (4e, Me).

$3 \mathrm{e}, \mathrm{Me}(3 R, 4 R):{ }^{1} \mathrm{H}$ NMR $(400 \mathrm{MHz}): \delta 1.10(3 \mathrm{H}, \mathrm{s})$, $3.78(3 \mathrm{H}, \mathrm{s}), 3.82(3 \mathrm{H}, \mathrm{s}), 4.14(1 \mathrm{H}, \mathrm{t}, J=6.6 \mathrm{~Hz}), 4.51$ $(1 \mathrm{H}, \mathrm{dd}, J=6.2,9.2 \mathrm{~Hz}), 4.68(1 \mathrm{H}, \mathrm{dd}, J=7.3,9.2 \mathrm{~Hz})$, $6.87(2 \mathrm{H}, \mathrm{d}, J=8.8 \mathrm{~Hz}), 7.08(2 \mathrm{H}, \mathrm{d}, J=8.8 \mathrm{~Hz}) .{ }^{13} \mathrm{C}$ NMR $(100.5 \mathrm{MHz}): \delta 15.85,48.50,53.42,55.37,70.65$, $114.44,127.9,129.03,159.3,171.0,175,2$. MS $[\mathrm{m} / \mathrm{z}(\%$ rel. int.)]: EI, $264(40, M), 233(9), 219$ (100), 205 (75), 188 (15), 150 (25), 121 (69),

3e, Me $(3 S, 4 R):{ }^{1} \mathrm{H}$ NMR $(400 \mathrm{MHz}): \delta 1.54(3 \mathrm{H}, \mathrm{s})$, 
$3.55(3 \mathrm{H}, \mathrm{s}), 3.56(1 \mathrm{H}, \mathrm{dd}, J=8.0,11.4 \mathrm{~Hz}), 3.79(3 \mathrm{H}$, s), $4.54[1 \mathrm{H}$, dd (apparent triplet), $J=8.1 \mathrm{~Hz}], 4.72$ $(1 \mathrm{H}, \mathrm{dd}, J=8.8,11.0 \mathrm{~Hz}), 6.87(2 \mathrm{H}, \mathrm{d}, J=8.8 \mathrm{~Hz}), 7.08$ $(2 \mathrm{H}, \mathrm{d}, J=8.8 \mathrm{~Hz}) .{ }^{13} \mathrm{C}$ NMR $(100.5 \mathrm{MHz}): \delta 19.26$, 46.0, 52.60, 55.34, 55.90, 69.17, 114.43, 125.46, 128.83, $159.78,168.80,175.5$. MS $[m / z$ (\% rel. int.)]: EI, $264(36$, M), 233 (4), 219 (24), 205 (21), 188 (7), 150 (92), $121(100)$.

4e,Me: ${ }^{1} \mathrm{H}$ NMR (400 MHz): $\delta 1.24(3 \mathrm{H}, \mathrm{d}, J=$ $7.0 \mathrm{~Hz}), 2.66(1 \mathrm{H}, \mathrm{m}), 3.25(1 \mathrm{H}, \mathrm{m}), 3.81(3 \mathrm{H}, \mathrm{s}), 4.09$ $(1 \mathrm{H}, \mathrm{dd}, J=9.2,10.6 \mathrm{~Hz}), 4.51[1 \mathrm{H}$, dd (apparent triplet $), J=8.8 \mathrm{~Hz}$ ], $6.90(2 \mathrm{H}, \mathrm{d}, J=8.4 \mathrm{~Hz}), 7.16(2 \mathrm{H}$, d, $J=8.4 \mathrm{~Hz})$. MS $[m / z(\%$ rel. int.)]: EI, $206(69, M)$, $161(12), 148(100)$.

Reaction of cyclic sulfite RR-2g with dimethyl 2-methylmalonate anion. The reaction was performed as described in the general procedure and the reaction time was $24 \mathrm{~h}$. One product was isolated: $(4 R, 5 R)-5$-methyl-4-phenyl1,3-dioxolan-2-one $(\mathbf{6 g})$.

Reaction of cyclic sulfites with ethyl acetoacetate aniongeneral procedure. Sodium hydride $(0.36 \mathrm{~g}$ of a $20 \%$ suspension, $3.0 \mathrm{mmol}$ ) was washed four times with petroleum ether (b.p. $40-60^{\circ} \mathrm{C}$ ) under dry nitrogen, dry DMF $(4 \mathrm{ml})$ was added and the resulting slurry was cooled in an ice bath. Ethyl acetoacetate $(0.39 \mathrm{~g}, 3.0 \mathrm{mmol})$ or ethyl 2-methylacetoacetate $(0.43 \mathrm{~g}, 3.0 \mathrm{mmol})$ was added, and the mixture was stirred a few minutes after the gas had evolved. The cyclic sulfite $(1.0 \mathrm{mmol})$ was added and the reaction mixture was heated to $70-80^{\circ} \mathrm{C}$. The reaction was monitored by $\mathrm{GC}$ and was quenched and worked up as described for the dimethyl malonate reactions.

Reaction of cyclic sulfite S-2a with ethyl acetoacetate anion. The reaction was performed as described in the general procedure and the reaction time was $22 \mathrm{~h}$. Several products were identified: $(4 R)-4,5$-dihydro-4-phenyl-2(3H)furanone $(4 \mathrm{a}, \mathrm{H}), \quad(4 S)$-4-phenyl-1,3-dioxolan-2-one (6a), ethyl $(1 R / S, 2 S)$-1-acetyl-2-phenylcyclopropanecarboxylate (10a), ethyl (3R)-4-acetoxy-3-phenylbutyrate $(11 \mathrm{a}, \mathrm{H})$ and a diastereomer mixture of $(2 R, 4 S)$ - and $(2 S, 4 S)$-2-(ethoxycarbonylmethyl)-2-methyl-4-phenyl1,3-dioxolan (12a, H).

4a,H: MS $[m / z(\%$ rel. int.)]: EI, $162(28, M), 131$ (3), $117(7), 104$ (100).

10a: MS $[m / z$ (\% rel. int.)]: EI, $232(100, M), 203$ (11), 186 (86), 158 (42).

11a,H: ${ }^{1} \mathrm{H}$ NMR (400 MHz): $\delta 1.14(3 \mathrm{H}, \mathrm{t}, J=$ $7.3 \mathrm{~Hz}), 2.00(3 \mathrm{H}, \mathrm{s}), 2.64(1 \mathrm{H}, \mathrm{dd}, J=8.4,15.8 \mathrm{~Hz})$, $2.77(1 \mathrm{H}, \mathrm{dd}, J=7.0,15.8 \mathrm{~Hz}), 3.50(1 \mathrm{H}, \mathrm{m}), 4.04(2 \mathrm{H}$, q, $J=7.3 \mathrm{~Hz}), 4.15(1 \mathrm{H}, \mathrm{dd}, J=7.3,11.0 \mathrm{~Hz}), 4.26(1 \mathrm{H}$, $\mathrm{dd}, J=6.2,11.0 \mathrm{~Hz}), 7.21-7.33(5 \mathrm{H}, \mathrm{m}) .{ }^{13} \mathrm{C} \mathrm{NMR}$ $(100.5 \mathrm{MHz}): \delta 14.17,20.90,37.71,41.16,60.57,67.57$, $127.28,127.74,128.67,140.32,170.84,171.74$. MS $[\mathrm{m} / z$ (\% rel. int.)]: EI, 205 (3), 190 (90), 178 (6), 163 (33), 135 (20), 118 (85), 104 (89). CI, $251(100, M+H)$.
12a,H (diastereomer mixture): ${ }^{1} \mathrm{H}$ NMR (400 MHz): $\delta 1.27(3 \mathrm{H}, \mathrm{t}, J=7.3 \mathrm{~Hz}), 1.61(0.67 \times 3 \mathrm{H}, \mathrm{s}), 1.68$ $(0.33 \times 3 \mathrm{H}, \mathrm{s}), 2.78(0.33 \times 2 \mathrm{H}, \mathrm{s}), 2.83(0.67 \times 2 \mathrm{H}, \mathrm{s})$, $3.73(1 \mathrm{H}, \mathrm{m}), 4.18(2 \mathrm{H}, \mathrm{m}), 4.33(1 \mathrm{H}, \mathrm{m}), \quad 5.09$ (1 H, m), 7.28-7.50 (5 H, m). ${ }^{13} \mathrm{C}$ NMR (100.5 MHz): $\delta$ $14.27,14.28,25.17,25.40,44.59,45.23,60.68,60.70$, 71.94, 72.09, 78.27, 78.5, 108.74, 108.84, 126.39-128.64, 137.91, 138.6, 169.45, 169.49. MS [m/z (\% rel. int.)]: EI, 235 (45), 220 (20), 190 (23), 163 (87), 144 (58), 131 (42), 120 (100). CI, $2(M+\mathrm{H})$.

Reaction of cyclic sulfite SS-2f with ethyl acetoacetate anion. The reaction was performed as described in the general procedure, but a higher temperature $\left(90-100^{\circ} \mathrm{C}\right)$ and 9 equiv. of sodium hydride and ethyl acetoacetate were used. The reaction time was 3 days. Four products were identified: ethyl $(1 R / S, 2 S, 3 S)$-1-acetyl-2,3-diphenylcyclopropanecarboxylate (10f), ethyl $(3 R, 4 R)$-4-acetoxy-3,4-diphenylbutyrate (11f, $\mathrm{H}),(2 R / \mathrm{S}, 4 S, 5 R)$-2-(ethoxycarbonylmethyl )-2-methyl-4,5-diphenyl-1,3-dioxolan $(\mathbf{1 2 f}, \mathrm{H})$ and $(4 S, 5 S)-4,5$-diphenyl-1,3-dioxolan-2-one (6f).

10f: MS $[m / z(\%$ rel. int.)]: $308(22, M), 266(13), 262$ (100), 247 (42), 220 (27), 219 (27) 191 (76).

11f,H: ${ }^{1} \mathrm{H}$ NMR $(400 \mathrm{MHz}): \delta 1.07(3 \mathrm{H}, \mathrm{t}, \quad J=$ $7,4 \mathrm{~Hz}), 1.92(3 \mathrm{H}, \mathrm{s}), 2.58(2 \mathrm{H}, \mathrm{dd}, J=6.8,8.8 \mathrm{~Hz})$, $3.67(1 \mathrm{H}, \mathrm{m}), 3.93(2 \mathrm{H}, \mathrm{q}, J=7.4 \mathrm{~Hz}), 5.95(1 \mathrm{H}, \mathrm{d}$, $J=7.8 \mathrm{~Hz}), 7.18-7.45(5 \mathrm{H}, \mathrm{m})$. MS $[\mathrm{m} / z$ (\% rel. int.)]: EI, $326(0.3, M), 283$ (2), 266 (5), 239 (15), 220 (14), 193 (11), 178 (61), 149 (72), 107 (100).

12f, $\mathrm{H}$ (diastereomer mixture): ${ }^{1} \mathrm{H}$ NMR (400 MHz): $\delta$ $1.28(0.4 \times 3 \mathrm{H}, \mathrm{t}, J=7.3 \mathrm{~Hz}), 1.34(0.6 \times 3 \mathrm{H}, \mathrm{t}, J=$ $7.3 \mathrm{~Hz}), 1.79(0.6 \times 3 \mathrm{H}, \mathrm{s}), 1.99(0.4 \times 3 \mathrm{H}, \mathrm{s}), 2.96$ $(0.4 \times 2 \mathrm{H}, \mathrm{s}), 3.12(0.6 \times 2 \mathrm{H}, \mathrm{s}), 4.20(0.4 \times 2 \mathrm{H}, \mathrm{q}, J=$ $7.3 \mathrm{~Hz}), 4.26(0.6 \times 2 \mathrm{H}, \mathrm{q}, J=7.3 \mathrm{~Hz}), 5.56(0.6 \mathrm{H}, \mathrm{s})$, $5.58(0.4 \mathrm{H}, \mathrm{s}), 6.98-7.09(5 \mathrm{H}, \mathrm{m})$. MS $[\mathrm{m} / z$ (\% rel. int.)]: 239 (21), 220 (84), 197 (33), 179 (30), 165 (14), $146(10), 132$ (100), 107 (34).

Reaction of cyclic sulfite RR-2g with ethyl acetoacetate anion. The reaction was performed as described in the general procedure but a higher temperature $\left(90-100^{\circ} \mathrm{C}\right)$ and 9 equiv. of sodium hydride and ethyl acetoacetate were used. The reaction time was 4 days. Three products were identified: methyl $(1 R / S, 2 R, 3 R)$-1-acetyl-2-phenylcyclopropanecarboxylate $(\mathbf{1 0 g})$, ethyl $(3 S, 4 R)$-3-phenyl-4acetoxypentanoate $(\mathbf{1 1 g}, \mathrm{H}),(2 R / S, 4 R, 5 S)$-2-(ethoxycarbonylmethyl) -2 -methyl -4 -phenyl -5 -methyl -1,3-dioxolan $(12 \mathrm{~g}, \mathrm{H})$, (4S,5R)-4,5-dihydro-5-methyl-4-phenyl-2$(3 H)$-furanone $(4 \mathrm{~g}, \mathrm{H})$ and $(4 R, 5 R)-5$-methyl-4-phenyl1,3-dioxolan-2-one (6g).

4g,H: MS $[m / z(\%$ rel. int.)]: $176(10, M), 148(5), 117$ (3), 115 (5), 104 (100).

10g: MS $[m / z(\%$ rel. int.)]: $246(48, M), 200(61), 158$ (13), 128 (45), 43 (100).

11g,H: ${ }^{1} \mathrm{H}$ NMR $(400 \mathrm{MHz}): \delta 1.10(6 \mathrm{H}, \mathrm{m}), 1.99$ (3 H, s), $2.61(2 \mathrm{H}, \mathrm{dd}, J=6.6,11.0 \mathrm{~Hz}), 3.34(1 \mathrm{H}, \mathrm{m})$, $4.01(2 \mathrm{H}, \mathrm{m}), 5.16(1 \mathrm{H}, \mathrm{m}) . \mathrm{MS}[\mathrm{m} / \mathrm{z}$ (\% rel. int.)]: EI, 
220 (13), 204 (100), 178 (34), 174 (11), 158 (17), 130 (28). CI, $265(45, M+\mathrm{H})$.

12g,H: ${ }^{1} \mathrm{H}$ NMR (400 MHz): (diastereomer mixture), $\delta 0.77(0.63 \times 3 \mathrm{H}, \mathrm{d}, J=6.6 \mathrm{~Hz}), 0.80(0.37 \times 3 \mathrm{H}, \mathrm{d}, J=$ $6.6 \mathrm{~Hz}), 1.26(0.37 \times 3 \mathrm{H}, \mathrm{t}, J=7.3 \mathrm{~Hz}), 1.29(0.63 \times 3 \mathrm{H}$, $\mathrm{t}, J=7.3 \mathrm{~Hz}), 1.60(0.63 \times 3 \mathrm{H}, \mathrm{s}), 1.80(0.37 \times 3 \mathrm{H}, \mathrm{s})$, $2.78(0.37 \times 2 \mathrm{H}, \mathrm{s}), 2.90(0.63 \times 2 \mathrm{H}, \mathrm{s}), 4.17(2 \mathrm{H}, \mathrm{m})$, $4.61(1 \mathrm{H}, \mathrm{m}), 5.24(0.37 \times 1 \mathrm{H}, \mathrm{d}, J=6.8 \mathrm{~Hz}), 5.25$ $(0.63 \times 1 \mathrm{H}, \mathrm{d}, J=6.8 \mathrm{~Hz}), 7.24-7.50(10 \mathrm{H}, \mathrm{m}) . \mathrm{MS}[\mathrm{m} / z$ (\% rel. int.)]: (diastereomer 1), EI, 249 (1), 220 (82), 202 (27), 174 (11), 177 (45), 158 (22), 134 (100), 132 (47), 128 (30). CI, $265(28, M+\mathrm{H})$. MS [ $m / z$ (\% rel. int.)]: (diastereomer 2), EI, 249 (11), 220 (100), 202 (29), 177 (10), 174 (8), 158 (22), 132 (43), 128 (25). CI, 265 $(61, M+\mathrm{H})$.

Reaction of cyclic sulfite S-2a with ethyl 2-methylacetoacetate anion. The reaction was performed as described in the general procedure and the reaction time was $24 \mathrm{~h}$. Three product groups were identified: $(3 R / S, 4 R)$ 4,5-dihydro-3-methyl-4-phenyl-2( $3 H$ )-furanone (4a,Me), ethyl $\quad(2 R / S, 3 R)$-4-acetoxy-3-phenyl-2-methylbutyrate (11a, Me) and $(2 R / S, 4 S)-2-[(R / S)$-1-ethoxycarbonylethyl]-2-methyl-4-phenyl-1,3-dioxolan (12a,Me).

11a,Me: (diastereomer 1) ${ }^{1} \mathrm{H}$ NMR (400 MHz): $\delta 0.96$ $(3 \mathrm{H}, \mathrm{d}, J=6.8 \mathrm{~Hz}), 1.29(3 \mathrm{H}, \mathrm{t}, J=6.8 \mathrm{~Hz}), 1.96(3 \mathrm{H}$, s), $2.78(1 \mathrm{H}, \mathrm{m}), 3.22(1 \mathrm{H}, \mathrm{m}), 4.18(3 \mathrm{H}, \mathrm{m}), 4.31$ ( $1 \mathrm{H}, \mathrm{m}), 7.17-7.34(5 \mathrm{H}, \mathrm{m}) .{ }^{13} \mathrm{C}$ NMR $(100.4 \mathrm{MHz}): \delta$ $14.21, \quad 15.93, \quad 20.81,42.23,47.33,60.61,66.68$, 127.41-128.93, 139.25, 170.72, 175.64. (Diastereomer 2) ${ }^{1} \mathrm{H}$ NMR (400 MHz): $\delta 1.02(3 \mathrm{H}, \mathrm{t}, J=6.8 \mathrm{~Hz}), 1.25$ $(3 \mathrm{H}, \mathrm{d}, J=6.8 \mathrm{~Hz}), 1.98(3 \mathrm{H}, \mathrm{s}), 2.89(1 \mathrm{H}, \mathrm{m}), 3.22$ $(1 \mathrm{H}, \mathrm{m}), 3.93(2 \mathrm{H}, \mathrm{q}, J=6.8 \mathrm{~Hz}), 4.38(2 \mathrm{H}, \mathrm{m})$, 7.17-7.34 (5 H, m). ${ }^{13} \mathrm{C}$ NMR (100.5 MHz): $\delta$ 13.94, $14.98,20.83,42.72,47.35,60.28,65.25,127.08-128.65$, $140.16,170.87,174.74$. (Both diastereomers) MS $[\mathrm{m} / z(\%$ rel. int.)]: EI, 219 (1), 204 (54), 189 (100), 177 (42), 161 (15), 135 (23), 131 (36), 118 (71). CI, 265 (5, M+H).

12a,Me: ${ }^{1} \mathrm{H}$ NMR (400 MHz): (diastereomer mixture) $\delta 1.22-1.36(6 \mathrm{H}, \mathrm{m}), 1.51$ and $1.59(3 \mathrm{H}, 2 \times \mathrm{d}, J=2.4$, $3.0 \mathrm{~Hz}), 2.91(1 \mathrm{H}, \mathrm{m}), 3.60$ and $3.72(1 \mathrm{H}, \mathrm{m}), 4.18$ $(2 \mathrm{H}, \mathrm{m}), \quad 4.28-4.41 \quad(1 \mathrm{H}, \mathrm{m}) \quad 5.01-5.16 \quad(1 \mathrm{H}, \mathrm{m})$ $7.28-7.48(5 \mathrm{H}, \mathrm{m})$. MS $[m / z$ (\% rel. int.)]: EI, $249(6)$, 234 (1), 203 (1), 163 (100), 143 (5), 129 (20). CI: 265 $(1, M+\mathrm{H})$.

Molecular modeling. Molecular modeling was performed using MacroModel v 5.0 software on a Silicon Graphics INDY workstation. To find all low-energy conformations for compounds $(3 S, 4 S)$-4,5-dihydro-4-(4-chlorophenyl)3 -methyl-2 $(3 H)$-furanone [ $3 S, 4 S)-4 \mathrm{~d}, \mathrm{Me}]$ and $(3 R, 4 S)-$ 4,5-dihydro-4-(4-chlorophenyl)-3-methyl-2(3H)-furanone $[(3 R, 4 S)-\mathbf{4 d}, \mathrm{Me}]$, a 3000 -step Monte Carlo conformational search using the MM2* force field and GB/SA chloroform solvent model was performed. Conformations were minimised with Polak-Ribiere conjugated gradient until the gradient was below $0.05 \mathrm{~kJ} \mathrm{~A}^{-1}$. For compound $(3 S, 4 S)-4 \mathrm{~d}, \mathrm{Me}$, two unique conformations were found with a difference in conformational energy of $3.5 \mathrm{~kJ} \mathrm{~mol}^{-1}$. For compound $(3 R, 4 S)$ $\mathbf{4 d}, \mathrm{Me}$, four unique conformations were found within $3.2 \mathrm{~kJ} \mathrm{~mol}^{-1}$ of the global minimum.

Acknowledgements. We thank the Norwegian Research Council for finacial support and we thank Merete L. Skar for performing the molecular modelling studies.

\section{References}

1. Ravid, U., Silverstein, R. M. and Smith, L. R. Tetrahedron 34 (1978) 1449.

2. Ohloff, G. Progress in the Chemistry of Organic Natural Products, Springer-Verlag, 1978, Vol. 35.

3. Ho, T.-L. Synth. Commun. 13 (1983) 341.

4. Günther, C. and Mosandl, A. Liebigs Ann. Chem. (1986) 2112.

5. Larchevêque, M., Tamagnan, G. and Petit, Y. J. Chem. Soc., Chem. Commun. (1989) 31.

6. Brand, J. M., Joung, J. C. and Silverstein, R. M. Progress in the Chemistry of Organic Natural Products, SpringerVerlag, 1979, Vol. 37.

7. Baker, R. and Rao, V. B. J. Chem. Soc., Perkin Trans. 1 (1982) 69.

8. Brownlee, R. G.. Silverstein. R. M.. Müller-Schwarze. D. and Singer, A. G. Nature 221 (1969) 284.

9. Mori, K., Ebata, T. and Takechi, S. Tetrahedron 40 (1984) 1761.

10. Tumlinson, J. H., Klein, M. G., Doolittle, R. E. and Proveaux, A. T. Science (1977) 789.

11. Tsuneya, T., Ishihara, M., Shiota, H. and Shiga, M. Agric. Biol. Chem. 44 (1980) 957.

12. Vigneron, J. P., Meric, R., Larchevêque, M., Debal, A., Kunesch, G., Zagatti, P. and Gallois, M. Tetrahedron Lett. 23 (1982) 5051.

13. Tomioka, K., Mizuguchi, H. and Koga, K. Tetrahedron Lett. (1978) 4687.

14. Gräfe, U., Reinhardt, G., Schade, W., Krebs, D., Eritt, I., Fleck, W. F., Heinrich, E. and Radics, L. J. Antibiot. 35 (1982) 609.

15. Pougny, J. R. Tetrahedron Lett. 25 (1984) 2363.

16. Stamatatos, L., Sinay, P. and Pougny, J. R. Tetrahedron 40 (1984) 1713.

17. Hanessian, S. Aldrichim. Acta 22 (1989) 3.

18. Stork, G. and Rychnovsky, S. D. Pure Appl. Chem. 58 (1986) 767.

19. Ziegler, F. E., Kneisley, A., Thottathil, J. K. and Wester, R. T. J. Am. Chem. Soc. 110 (1988) 5434.

20. Hanessian, S. Acc. Chem. Res. 12 (1979) 159.

21. Kunz, T., Janowitz, A. and Reißsig, H.-U. Chem. Ber. 122 (1989) 2165.

22. Stork, G. and Sher, P. M. J. Am. Chem. Soc. 105 (1983) 6765.

23. Hoppe, D. and Brönnecke, A. Tetrahedron Lett. 24 (1983) 1687.

24. Kraus, G. A. and Landgrebe, K. Tetrahedron Lett. 25 (1984) 3939.

25. Frauenrath, H. and Philipps, T. Liebigs Ann. Chem. (1985) 1951

26. Ueno, Y., Moriya, O., Chino, K., Watanabe, M. and Okawara, M. J. Chem. Soc., Perkin Trans. 1 (1986) 1351.

27. Fang, J.-M., Hong, B.-C. and Liao, L.-F. J. Org. Chem. 52 (1987) 855.

28. Black, T. H., Hall, J. A. and Sheu, R. G. J. Org. Chem. 53 (1988) 2371

29. Black, T. H. and Fields, J. D. Synth. Commun. 18 (1988) 125. 
30. Fukuzawa, S., Nakanishi, A., Fujinami, T. and Sakai, S. J. Chem. Soc., Perkin Trans. 1 (1988) 1669.

31. Linderman, R. J. and McKenzie, J. R. Tetrahedron Lett. 29 (1988) 3911.

32. Davies, S. G., Middlemiss, D. M., Naylor, A. and Wills, M. Tetrahedron Lett. 30 (1989) 587.

33. Sturm, T.-J., Marolewski, A. E., Rezenka, D. S. and Taylor, S. K. J. Org. Chem. 54 (1989) 2039.

34. Chen, S.-Y. and Joullié, M. M. J. Org. Chem. 49 (1984) 2168.

35. Albinati, A., Bravo, P., Ganazzoli, F., Resnati, G. and Viani, F. J. Chem. Soc., Perkin Trans. 1 (1986) 1405.

36. Solladié, G. and Matloubi-Moghadam, F. J. Org. Chem. 47 (1982) 91

37. Lohray, B. B. Synthesis (1992) 1035.

38. Markó, I. E. and Svendsen, J. S. In: Hegedus, L., Ed., Comprehensive Organometallic Chemistry, Pergamon, London 1995, Vol. 12.

39. Nymann, K. and Svendsen, J. S. Acta Chem. Scand. 48 (1994) 183.

40. Sharpless, K. B., Amberg, W., Beller, M., Chen, H., Hartung, J., Kawanami, Y., Lübben, D., Manoury, E.,
Ogino, Y., Shibata, T. and Ukita, T. J. Org. Chem. 56 (1991) 4585.

41. Sharpless, K. B., Amberg, W., Bennani, Y. L., Crispino, G. A., Hartung, J., Jeong, K.-S., Kwong, H.-L., Morikawa, K., Wang, Z.-M., Xu, D. and Zhang, X.-L. J. Org. Chem. 57 (1992) 2768.

42. Gao, Y. and Sharpless, K. B. J. Am Chem. Soc. 110 (1988) 7538.

43. Haasnoot, C. A. G., de Leeuw, F. A. A. M. and Altona, C. Tetrahedron 36 (1980) 2783

44. Mohamadi, F., Richards, N. G. J., Guida, W. C., Liskamp, R., Lipton, M., Caufield, C., Chang, G. Hendrickson, T. and Still, W. C. J. Comput. Chem. 11 (1990) 440.

45. Nymann, K., Jensen, L. and Svendsen, J. S. Acta Chem. Scand. 50 (1996) 832.

46. Nalesnik, T. E., Freudenberger, J. H. and Orchin, M. J. Organomet. Chem. 236 (1982) 95.

47. Kolsaker, P. and Jensen, A. K. Acta Chem. Scand, Ser. B 42 (1988) 345.

Received May 21, 1997. 